\title{
The Use of Crude Extract of Alhagi graecorum and Urtica pilulifera in the Treatment of Chronic Inflammation of Seminal Fluid: A Case Study
}

\author{
Ahed J Alkhatib* \\ Department of Legal Medicine, Jordan \\ *Corresponding author: Ahed J Alkhatib, Department of Legal Medicine, Jordan
}

\begin{abstract}
Introduction: Although, the medicines have been widely developed at global level, herbal treatments are still used by many patients for both being cheap and safe treatments.

Objectives: The main objective of the present study is to report a living experience of a patient with chronic inflammation of seminal fluid for 12 years.

Study case: We introduced a case of having seminal fluid infection for 12 years. The patient has used several types of antibiotics and developed multiple resistances for antibiotics. The patient and his family decided to look for other therapeutic approaches such as herbal products. We described in this study how successfully the patient was treated.
\end{abstract}

Keywords: Seminal fluid; Infection; Herbal treatment; Alhagi graecorum; Urtica pilulifera

\section{Introduction}

The use of herbal products for therapeutic purposes has begun since prehistoric times [1,2]. At global level, people used herbal medicine for various purposes such as the treatment, control and management of variety of diseases [3-6]. Several studies including ours have revealed the therapeutic potential of Urtica (Urticaceae), or stinging nettle [7]. As illustrating examples, several studies have demonstrated hypotensive properties of Urtica [8,9]. Several therapeutic uses of Urtica have been reported including antiinflammatory effects [10], prostatic hyperplasia [11,12], diuretic [13] and immunomodulatory activity [14-17], to relieve rheumatic pain [18], and rheumatoid arthritis [19]. Another herb of interest is Alhagi graecorum, also known as Camel thorn [20]. It is used for different medical purposes [21-24]. Numerous studies showed the importance of using Alhagi plants in treating a variety of diseases such as shingles [20], gastroenteritis, ulcers, fever, inflammations and angina pain, headache and toothache, rheumatoid arthritis, liver disorders, kidney stone and urinary tract infections, hypertension and cancer [25-34]. In the present study, we introduce our experience in treating seminal fluid infection by using the water crude extract of both Alhagi graecorum and Urtica pillulifera for the first time up to the best knowledge of the researcher.

\section{Study Case}

A case of a male patient with inflammation in seminal fluid over 12 years is presented. The most prominent feature was highly increased number of white blood cells in seminal fluid in the range of 100-120 cells/HPF. During that time, the patient visited various private clinics and hospitals and he was prescribed several types of antibiotics. This case was considered a typical case of antibiotic abuse either in the level of individual or in the medical level. The benefit of antibiotic treatment was very limited which requires the patient and his relatives to seek for other alternative therapeutics. The patient was advised to intake the crude extract of two herbal plants: Alhagi graecorum and Urtica pilulifera for three months in the following pattern: A cup of $200 \mathrm{ml}$ of Urtica pilulifera in the morning with some sugar, and a cup of $200 \mathrm{ml}$ of Alhagi graecorum in the evening. 


\section{Results}

After the treatment time had finished, a seminal analysis was carried out, and the results were amazing, the white blood cells in seminal fluid were 5 cells/HPF.

\section{Conclusion}

The present study showed that the double treatment of Alhagi graecorum and Urtica pilulifera can be effectively used against chronic inflammation of seminal fluid without side effects.

\section{Recommendation}

We recommend studying the therapeutic effects of these herbal plants in depth against other inflammatory diseases.

\section{References}

1. Alsarhan A, Sultana N, Khatib AA, Abdul Kadir MR (2014) Review on some Malaysian traditional medicinal plants with therapeutic properties. Journal of Basic \& Applied Sciences 10: 149-159.

2. Chikezie PC, Ojiako OA (2015) Herbal medicine: Yesterday, today and tomorrow. Altern Integr Med 4: 195.

3. Griggs B, Van der Zee B (1981) Green pharmacy: A history of herbal medicine. J Morman \& Hobhouse Ltd. London.

4. Kinghorn AD, Balandrin MF (1993) Human medicinal agents from plants. America Chemical Society. San Francisco, USA, p. 534.

5. Kong JM, Goh NK, Chia LS, Chia TF (2003) Recent advances in traditional plant drugs and orchids. Acta Pharmacol Sin 24(1): 7-21.

6. Philipeon JD (2003) Phytochemistry and medicinal plants. Phytother 56 237-243.

7. Mousa H, Al Shuwayeb, Al Khatib AJ (2013) Molecular and chemical therapeutic features of Urtica species. European Scientific Journal 9(24): 253-261.

8. Granier G, Beauquense BL, Debraux G (1961) Resources medicinales de la flore Francaise. Vigot Freres, Paris 2: 962-964.

9. Ziyyat A, Legssyer A, Mekhfi H, Dassouli A, Serhrouhni M, et al. (1997) Phytotherapy of hypertension and diabetes in oriental Morocco. J Ethnopharmacol 58(1): 45-54.

10. Reihemann K, Behnke B, Osthoff SK (1999) Plant extract from stinging nettle (Urtica dioica), an antirheumatic remedy, inhibit the proinflammatory transcription factor. FEBS Lett 442(1): 89-94.

11. Krzeski T, Kazon M, Brokowski A, Witeska A, Kuczera J (1993) Combined extracts Urtica dioica and Pygeum african in the treatment of hyperplasia: Double-blind comparison of two doses. Clin Ther 15(6): 1011-1020.

12. Lichius JJ, Muth C (1997) The inhibiting effect of Urtica dioica root extracts on experimentally induced prostatic hyperplasia in the mouse. Planta Med 63(4): 307-310.

13. Tahri A, Sabah Y, Legssyer A, Aziz M, Mekhfi H, et al. (2000) Acute diuteric, natriuretic and hypotensive effects of a continuous perfusion of aqueous extract of Urtica dioica in the rat. J Ethnopharmacol 73(1-2): 95-100.

14. Delcourt M, Peumans WJ, Wanger MC, Bachi TP (1996) V beta specific deletion of mature thymocytes induced by the plant superantigen Urtica dioica agglutinin. Cell Immunol 168(2): 158-164.

15. Musette P, Galelli A, Chabre H, Callard P, Peumans W, et al. (1996) Urtica dioica agglutinin, a V beta 8.3-specific superantigen, prevents the development or the systemic lupus erythematosus like pathology of MRL Ipr/Ipr mice. Eur J Immunol 26(8): 1707-1711.

16. Basaran AA, Ceritoglu I, Undeger U, Basaran N (1997) Immunomodulatory activities of some Turkish medicinal plants. Phytother Res 11 (8): 609611.

17. Rovira P, Buckle M, Abastado JP, Peumans WJ, Bachi TP (1999) Major histocompatibility class I molecules present Urtica dioica agglutinin, a superrantiden of vegetal origin to lymphocytes. Eur J Immunol 29(5): 1571-1580.

18. Chrubasik S, Eisenberg E (1999) Treatment of rheumatic pain with medicine in Europe. Part 2. Urtica dioica L. Pain Clinic 11(3): 179-185.

19. Randall C, Mccthan K, Randall H, Dobbs F (1999) Nettle sting of Urtica dioica for joint pain: An exploratory study of this complementary therapy. Complement Ther Med 7(3): 126-131.

20. Alkhatib AJ (2017) The Extract of Alhagi graecorum in Olive Oil in the Treatment of Herpes Zoster (Shingles): A case report study. EC Microbiology 10(4): 137-140.

21. Gholamhoseinian A, Razmi Z (2012) Screening the methanolic extracts of some plants for tyrosinase inhibitory activity. Toxicological \& Environmental Chemistry 94(2): 310-318.

22. Laghari AH, Memon S, Nelofar A, Khan KM (2012) Antifungal ursenetype triterpene from the roots of Alhagi camelorum. Helvetica Chimica Acta 95(9): 1556-1560.

23. Zou GA, Mansur S, Hu SC, Aisa HA, Shakhidoyatov KhM (2012) Pyrrole alkaloids from Alhagi sparsifolia. Chemistry of Natural Compounds 48(4): 635-637.

24. Seredin RM, Sokolov SD (1978) Medicinal plants and their uses [in Russian]. Stavropol'skoe Knizhnoe Izd, Stavropo.

25. Boulos L (1983) Medicinal plants of North Africa. Reference Publications Inc: Cairo, Egypt, p. 368.

26. Amani AS, Maitland DJ, Soliman GA (2006) Antiulcerogenic activity of Alhagi maurorum. Pharmaceutical Biology 44 (4): 292-296.

27. Marwat SK, Khan MA, Ahmad M, Zafar M, Rehman FU (2008) Ethnophyto medicines for treatment of various diseases in D. I. Khan district. Sarhad J Agric 24(2): 306-316.

28. Varshney K, Singh AK (2008) Inventory of some ethnomedicinal plant species used by rural people of Etah district, India. Plant Archives 8(2): 757-759.

29. Khan FM (2009) Ethno-veterinary medicinal usage of flora of greater Cholistan desert (Pakistan). Pakistan Veterinary Journal 29(2): 75-80.

30. Al Douri NA, Al Essa LY (2010) A survey of plants used in Iraqi traditional medicine. Jordan Journal of Pharmaceutical Sciences 3(2): 100-108.

31. Shaker E, Mnaa SMH (2010) Anti-inflammatory and antiulcer activity of extract of Alhagi maurorum (camelthorn). Food Chem Toxicol 48(10): 2785-2790.

32. Badshah L, Hussain F (2011) People preferences and use of local medicinal flora in district Tank, Pakistan". Journal of Medicinal Plants Research 5(1): 22-29.

33. Kouchmeshky A, Jameie SB, Amin G, Ziai SA (2012) Investigation of ACE inhibitory effects of medicinal plants used in traditional Persian medicine for treatment of hypertension: Screening study. THRITA Student Journal of Medical Sciences 1(1): 13-23.

34. Laghari AH, Memon AA, Memon S, Nelofar A, Khan KM, et al. (2012) Determination of free phenolic acids and antioxidant capacity of methanolic extracts obtained from leaves and flowers of camel thorn (Alhagi maurorum). Nat Prod Res 26(2): 173-176. 


Open Access Journal of Complementary
\& Alternative Medicine
Assets of Publishing with us
- Global archiving of articles
- Immediate, unrestricted online access
- Rigorous Peer Review Process
- Authors Retain Copyrights
- Unique DOI for all articles

